\title{
Methylation of estrogen receptor $\beta$ promoter correlates with loss of ER- $\beta$ expression in mammary carcinoma and is an early indication marker in premalignant lesions
}

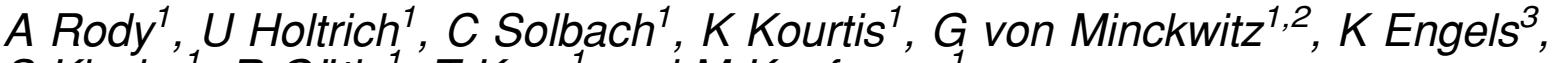

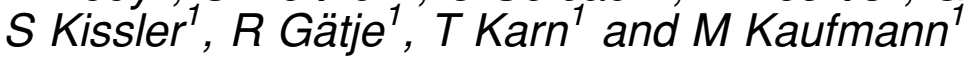

\footnotetext{
${ }^{1}$ Department of Gynecology, Johann Wolfgang Goethe University, Theodor-Stern-Kai 7, 60590 Frankfurt, Germany

${ }^{2}$ German Breast Group, Schleussnerstrasse 42, 63263 Neu-Isenburg/Frankfurt, Germany

${ }^{3}$ Department of Pathology, Johann Wolfgang Goethe University, Theodor-Stern-Kai 7, 60590 Frankfurt, Germany
}

(Requests for offprints should be addressed to T Karn; Email: t.karn@em.uni-frankfurt.de)

\begin{abstract}
The function of estrogen receptor beta (ER- $\beta$ ) in mammary tissue is not completely understood. While early observations were often conflicting, more recent data suggest an important role as a tumor-suppressor gene. A decrease of ER- $\beta$ expression has been observed in ductal carcinoma in situ and invasive carcinoma as compared with benign mammary epithelial cells. The loss of ER- $\beta$ resulted in abnormal growth of mammary epithelial cells. We have previously shown that the mRNA expression of the ER- $\beta$ gene is almost totally suppressed in breast carcinomas from patients with a poor prognosis. Here we analyzed whether methylation changes in the different promoters of ER- $\beta$ are responsible for the loss of expression of the gene. A methylation assay with high specificity and sensitivity was developed, and a panel of breast tissue samples $(n=175)$ was characterized for methylation status. In contrast to benign breast, more than two-thirds of invasive breast cancers showed a high degree of methylation. Importantly, increased methylation was also detectable in numerous premalignant lesions. By analysis of breast tumors, previously characterized by geneexpression profiling, methylation was predominantly detected in a subgroup of patients with an unfavorable prognosis, suggesting a possible prognostic value of the ER- $\beta$ methylation status. We also investigated the structural characteristics of the two ER- $\beta$ promoters, which were both found to be closely associated with a second, downstream, localized and opposite-oriented promoter. However, we could not detect endogenous antisense RNA transcribed from these promoters, which may be involved in epigenetic gene silencing. We also failed to induce ER- $\beta$ promoter methylation by expressing siRNAs in cell lines. Interestingly, by comparing the promoter sequences of ER- $\beta$ with other genes known to be epigenetically inactivated in breast cancers, we identified a sequence motif possibly involved in promoter methylation.
\end{abstract}

Endocrine-Related Cancer (2005) 12 903-916

\section{Introduction}

DNA methylation is a ubiquitous process of gene inactivation in nature (reviewed in Bird 2002). It occurs preferentially at $\mathrm{CpG}$ dinucleotides. In normal cells, most of the 5-methyl-cytosine is found to be associated with repetitive elements such as Alus or LINEs, whereas $\mathrm{CpG}$ islands (CGI), GC-rich stretches, hundreds of base pairs long, remain hypomethylated. These CGI often become densely methylated as cells undergo malignant transformation. It has been shown that methylation of $\mathrm{CpGs}$ can interfere with gene transcription and induce genomic imprinting, such as $\mathrm{X}$ chromosome inactivation. Although it is clear that methylation of DNA is driven by at least three functionally and structurally related methyltransferases, little information is currently available on which proteins participate in the guiding of methyltransferases to target sequences. One model for regulation of epigenetic gene silencing is that of elements 
encoding antisense RNA, a mechanism involved in $\mathrm{X}$ chromosome inactivation and autosomal imprinting (reviewed in Ogawa \& Lee 2002). In X chromosome inactivation, TSIX transcripts serve as an antisense regulator of the silencer element XIST, which itself makes a noncoding transcript. Imprinting by naturally occurring antisense transcripts (NATs) has also been detected in various autosomally loci (O'Neill 2005), as in the Beckwith-Wiedemann syndrome locus (Fitzpatrick et al. 2002), the Prader-Willi/Angelman syndrome locus (Mann \& Bartolomei 1999) and the IGF2R/AIR locus (Zwart et al. 2001). However, exactly how these transcripts contribute to epigenetic silencing remains to be elucidated. Recently, Brenner et al. (2005) have shown that Myc binds the corepressor Dnmt3a and associates with DNA methyltransferase activity in vivo, suggesting a new mechanism in which targeting of DNA methyltransferases via transcription factors may establish specific cellular $\mathrm{CpG}$ methylation patterns.

It is commonly accepted that estrogens and their receptors play a pivotal role in development and growth of invasive breast cancer. The role of estrogen receptor beta (ER- $\beta)$ in breast cancer is not completely understood, but there is strong evidence that ER- $\beta$ may act as a tumor-suppressor gene (reviewed in Matthews \& Gustafsson 2003, Bardin et al. 2004). By gene-expression profiling, we have previously demonstrated that in breast cancer with an unfavorable prognosis (Ahr et al. 2002) the expression of the ER- $\beta$ gene is almost completely suppressed (Ahr et al. 2001). Skliris et al. (2003) found a gradual decrease of ER- $\beta$ protein in normal mammary epithelial cells, ductal carcinoma in situ and invasive breast cancer. A complete loss of ER- $\beta$ expression was seen in $21 \%$ of invasive carcinomas, but more often in invasive-ductal than in invasive-lobular cancers. Furthermore, by introducing the ER- $\beta$ gene coding sequence, Paruthiyil et al. (2004) demonstrated an inhibition of proliferation of MCF-7 cells through repression of c-myc, cyclin D1 and cyclin A gene expression and an increased expression of $\mathrm{p} 21^{\text {cip } 1}$ and $\mathrm{p} 27^{\mathrm{kip} 1}$, resulting in G2 cell-cycle arrest. Roger et al. (2001) found a decreased expression of ER- $\beta$ protein by immunohistochemistry in premalignant breast lesions. All these data underline the function of ER- $\beta$ as a tumorsuppressor gene and its crucial role in breast cancer development. Regarding possible mechanisms for regulation of ER- $\beta$ mRNA expression, two different promoters, $0 \mathrm{~K}$ and $0 \mathrm{~N}$, have been detected for the human ER- $\beta$ gene (Zhao et al. 2003, Zhu et al. 2004). Zhao et al. reported that while promoter $0 \mathrm{~N}$ of the ER- $\beta$ gene is not methylated in normal mammary epithelial cells, it is highly methylated in breast cancer cell lines. Promoter $0 \mathrm{~K}$, in contrast, seems to be methylated neither in normal nor in cancer cells. Moreover, re-expression of the ER- $\beta$ mRNA in cell lines was obtained by experimental demethylation. These results are also in good agreement with data of Zhu et al. (2004) concerning methylation of promoter $0 \mathrm{~N}$ in prostate carcinoma cells. In the analyses presented here, we examined the methylation status of the ER- $\beta$ promoters in benign human breast tissue, corresponding premalignant epithelial lesions and ductal carcinoma in situ, as well as in invasive breast cancer. Our results confirm that methylation is confined to promoter $0 \mathrm{~N}$. A methylation assay with high specificity and sensitivity for the CGI associated with promoter $0 \mathrm{~N}$ was developed, and it revealed a close correlation between ER- $\beta$ mRNA expression and methylation. In contrast to benign breast, more than two-thirds of invasive breast cancers show a high degree of methylation. Importantly, methylation changes are already detectable in premalignant lesions. By analysis of a panel of breast tumors, previously characterized by gene-expression profiling, methylation was predominantly detected in a subgroup of patients with an unfavorable prognosis, suggesting a possible prognostic value of the ER- $\beta$ methylation status. Furthermore, we investigated the structural characteristics of the two ER- $\beta$ promoters, which were both found to be closely associated with a second, downstream localized and opposite-oriented promoter. However, we could not detect endogenous antisense RNA transcribed from these promoters, which may be involved in epigenetic gene silencing. We also failed to induce ER- $\beta$ promoter methylation by expressing siRNA in cell lines. However, by comparing the promoter sequences of ER- $\beta$ with other genes known to be epigenetically inactivated in breast cancers, we identified a sequence motif possibly involved in promoter methylation.

\section{Materials and methods}

\section{Tissue samples}

Tissue samples were obtained from patients undergoing surgical resection between June 1997 and June 2004 at the Department of Obstetrics and Gynecology of the J W Goethe University (Frankfurt). The samples were fresh frozen in liquid nitrogen and stored at $-196^{\circ} \mathrm{C}$. Specimens included ductal and lobular carcinomas of different tumor size, lymph-node status, grade, ER- $\alpha$ status and distant metastasis. In addition, several types of premalignant lesions of the breast were analyzed, including papilloma, fibroadenoma, 
mastopathy, ductal hyperplasia, and ductal carcinoma in situ (DCIS). Normal tissue samples were obtained from patients undergoing surgical breast reduction. Cell culture of cell lines was performed as described (Hock et al. 1998).

\section{Analysis of mRNA expression by real-time PCR}

Total RNA from human primary mammary carcinomas was isolated by the guanidinium isothiocyanate method, as previously described (Holtrich et al. 1994), in combination with affinity purification (Rneasy; Qiagen). Real-time PCR analyses were performed with the ABI 7700 Sequence Detection System (PE-Applied Biosystems, Foster City, CA, USA). cDNAs were generated by random-primed reverse transcription (RT) (ProSTAR cDNA synthesis kit; Stratagene, La Jolla, CA, USA). PCRs were performed according to the manufacturer's protocols (PE-Applied Biosystems). VIC-fluorophore-labeled GAPDH TaqMan probes served as internal quantification markers in the multiplex PCRs. Each quantitation was reproduced three times and normalized by GAPDH.

\section{DNA isolation and bisulfite conversion}

DNA isolation from tissue samples and cultured cells was performed according to standard protocols after digestion with proteinase $\mathrm{K}$, as described previously (Holtrich et al. 1991).

Prior to bisulfite modification, $500 \mathrm{ng}$ DNA were boiled for $1 \mathrm{~min}$ and then treated with $0.3 \mathrm{M} \mathrm{NaOH}$ for $15 \mathrm{~min}$ at $37^{\circ} \mathrm{C}$. It is critical that the bisulfite modification of unmethylated cytosine is complete; otherwise, the unconverted cytosine residues will appear as pseudomethylated sites. Therefore, this step was optimized with control DNA templates. In the optimized protocol, freshly denatured DNA was embedded in $10 \mu 12 \%$ agarose beads to inhibit reassociation of the DNA strands during the conversion reaction. The DNA was then reacted with $3 \mathrm{M}$ bisulfite and $10 \mathrm{mM}$ hydroquinone, $\mathrm{pH}$ 5.0. The conversion reaction was performed under oil in a thermocycler at $50^{\circ} \mathrm{C}$ with repeated heating steps to $80^{\circ} \mathrm{C}$ for $3 \mathrm{~min}$ each for $180 \mathrm{~min}$ (total of five cycles). The beads were then washed six times with $0.9 \mathrm{ml} \mathrm{H}_{2} \mathrm{O}$, incubated two times in $1 \mathrm{M} \mathrm{NaOH}$ for $15 \mathrm{~min}$ for alkaline desulfonation, and finally washed in Tris- $\mathrm{HCl}$ ( $\mathrm{pH} \mathrm{7.5)} \mathrm{for} 15 \mathrm{~min}$.

\section{Methylation-specific PCR (MSP) assay}

After bisulfite treatment, $10 \mu$ distilled water were added to the agarose beads containing the converted
DNA. Beads were melted and $7 \mu 1$ added to first-round PCR using primers U1 and L1 for 45 cycles: 1 min at $95^{\circ} \mathrm{C}, 2 \mathrm{~min}$ at $55^{\circ} \mathrm{C}$ and $2 \mathrm{~min}$ at $72^{\circ} \mathrm{C}$. The $\mathrm{U} 1$ and $\mathrm{L} 1$ primers are located at sites devoid of $\mathrm{CpG}$ dinucleotides to allow an unbiased amplification of both methylated and unmethylated DNA. PCR was allowed to reach a plateau, and then the amplicons were diluted $10^{-2}$ to give a normalized input amount for a second nested PCR. Second-round PCR was performed with SYBR green for real-time detection. The upper primer U2 was used in combination with lower primer $\mathrm{L} 2$ for detection of methylation. To assess the extent of conversion, the primer U3 was used with the L2 primer. Second-round PCR cycle conditions were $1 \mathrm{~min}$ at $95^{\circ} \mathrm{C}, 1 \mathrm{~min}$ at $60^{\circ} \mathrm{C}$ and $2 \mathrm{~min}$ at $72^{\circ} \mathrm{C}$ for 40 cycles. Primer positions according to GenBank accession no. AL161756 were as follows: 82,194-82,215 (U1), 82,232-82,254 (U2), 82,285-82,306 (U3), 82,459-82,480 (L1) and 82,40382,426 (L2).

\section{Detection of antisense transcripts}

An RT-based real-time PCR strategy was used to detect endogenous antisense transcripts originating from the reverse-oriented promoter. RNA was isolated from methylated (MDA-MB-435) and unmethylated (MCF-7) cell lines and from mammary carcinoma tissues positive and negative for methylation. Genomic DNA was removed from the RNA with two rounds of DNase digestion on Qiagen columns. The extent of DNA depletion was assessed by real-time PCR. Next, cDNA synthesis was specifically primed with several sense primers located $5^{\prime}$ from the reverse-oriented promoter in the region encompassing promoter $0 \mathrm{~N}$ (nt positions 81,283, 81,822, 82,305, 82,797, 83,208 and 83,655 according to accession no. AL161756). Since RNA tends to self-prime during cDNA synthesis, controls without the addition of primer were included. Specificity of the priming was checked by real-time PCR of sense transcripts, using GPDH and ESR2 as negative controls.

\section{shRNA transfection for induction of RNAi-mediated promoter methylation}

Induction of promoter methylation through RNAi processes, as described by Kawasaki and Taira (2004) and Morris et al. (2004), was examined. shRNAs were expressed by the human U6 promoter in cell lines to generate type Ia siRNA (Schwarz et al. 2003, Ui-Tei et al. 2004) targeted on different $\mathrm{CpG}$ sites in the promoter $0 \mathrm{~N}$ of ER- $\beta$. U6-shRNAs were generated by PCR according to Castanotto et al. (2002). Synthesis 
of the U6 containing hairpin constructs was monitored by SYBR green fluorescence and stopped before the reaction reached saturation. After an initial incubation at $95^{\circ} \mathrm{C}$ for $9 \mathrm{~min}$, cycles consisted of $1 \mathrm{~min}$ at $95^{\circ} \mathrm{C}$, $1 \mathrm{~min}$ at $60^{\circ} \mathrm{C}$ and $3 \mathrm{~min}$ at $79^{\circ} \mathrm{C}$. An elongation temperature of $79^{\circ} \mathrm{C}$ was necessary to disrupt the hairpin structure in order to allow efficient amplification and monitoring of SYBR fluorescence during cycling. PCR products were purified on QiaQuick columns (Qiagen) and used for transfection of MCF-7, T47D, MDA-MB-468 and HEK293 cells with lipofectamine (Gibco). Efficiencies were monitored by cotransfecting pEGFP-C1 (Clontech) and varied from 20 to $100 \%$. After harvest of the cells on days 2, 5 and 10 , the methylation status of ER- $\beta$ was determined by MSP.

\section{Bioinformatic analysis and database searches}

Online resources, including FASTA and BLAST services from NCBI (www.ncbi.nlm.nih.gov/BLAST/) and EBI (www.ebi.ac.uk/services/), were used for sequence analysis. CGI were identified by the method of Takai and Jones (2002) with the CGI finder program, version 10/29/04, available at http:// cpgislands.usc.edu/. Promoter predictions were performed with PROSCAN (Prestridge 1995), Version 1.7 (http://thr.cit.nih.gov/molbio/proscan/). For further sequence analysis, the HUSAR sequence analysis package (http://genius.embnet.dkfz-heidelberg.de/menu/ biounit/) was applied, including the FINDPATTERN program. The ONCOMINE 2.0 database (Rhodes et al. 2004, www.oncomine.org) was used as an interface to access published microarray data sets. To analyze downregulation of genes, data sets of Sorlie et al. (2001), comparing seven benign breast tissues (four normal breast samples and three fibroadenomas) with 78 breast cancer samples, and Perou et al. (2000), comparing three normal breast samples and one fibroadenoma with 55 ductal carcinomas, were used. To check for confounding effects of lymphocytes, a data set of van't Veer et al. (2002) from breast cancers either positive $(n=28)$ or negative $(n=89)$ for lymphocytic infiltration was used. Statistical analyses (Fisher's exact test and Student's $t$-test) were done with SPSS 11.5 (SPSS Inc., Chicago, IL, USA) and R 1.7 (www.R-project.org).

\section{Results}

\section{5 -Structure of the human ER- $\beta$ gene and development of a methylation assay}

The sequence of the genomic context of the human ER- $\beta$ gene (ESR2) located on chromosome 14 was obtained from BAC clone R-712C19 (accession no. AL161756; Heilig et al. 2001). A thorough analysis of the $90 \mathrm{~kb}$ DNA sequence upstream of the first exon of ESR2 revealed a $5^{\prime}$-structure of the gene as represented in Fig. 1. Two CGI-associated promoters, separated by approximately $40 \mathrm{~kb}$ (referred to as promoter $0 \mathrm{~K}$ and $0 \mathrm{~N}$ according to Li et al. 2000 and Zhao et al. 2003), were predicted in sense orientation by the PROSCAN program (Prestridge 1995). Interestingly, both promoters were associated with a $5^{\prime}$-Alu repeat and immediately followed $3^{\prime}$ by reverse promoters with opposite orientation. The CGI associated with promoter $0 \mathrm{~K}$ contained $86 \mathrm{CpG}$ sites; the one associated with promoter $0 \mathrm{~N}$ contained 55 sites. We used MSP in a screening approach to compare the methylation status of both promoters in benign breast samples with those in breast cancer specimens with known loss of ER- $\beta$ mRNA expression. Although we were not able to detect differences in the methylation status of promoter $0 \mathrm{~K}$, the CGI of promoter $0 \mathrm{~N}$ seemed to be heavily methylated in tumor samples (data not shown). Since MSP analysis as typically performed is often imperfect in both specificity and sensitivity, we next optimized the methylation assay by focusing on a CpG site located in promoter $0 \mathrm{~N}$ (nt position 82,254 of accession no. AL161756). This site displayed a consistently high methylation content among all analyzed breast cancer samples with lost ER- $\beta$ expression in the first scan. As depicted in Fig. 1, this assay employs a two-step PCR strategy. One major concern of methylation analyses is the occurrence of pseudomethylated sites caused by incomplete $\mathrm{C}-\mathrm{U}$ transition during bisulfite treatment (reviewed in Rein et al. 1998). Therefore, control amplifications were included in the second step, which tests for completeness of conversion of a non-CpG cytosine nucleotide (Fig. 1) (nt position 82,306 of accession no. AL161756), allowing for optimization of the bisulfite reaction conditions (see Methods). Under standard bisulfite reaction conditions $\left(50^{\circ} \mathrm{C}\right.$ overnight incubation) (Frommer et al. 1992, Herman et al. 1996), we observed conversion efficiencies far below the optimum, making it difficult reliably to detect actually methylated $\mathrm{CpG}$ sites. Thus, we employed the modified method described by Olek et al. (1996), using agarose bead-embedded DNA, which was then further optimized by repeated heating steps during incubation, as proposed by Rein et al. (1997). Five intervening treatments at $80^{\circ} \mathrm{C}$ for $3 \mathrm{~min}$ during the $50^{\circ} \mathrm{C}$ incubation yielded high $\mathrm{C}-\mathrm{U}$ conversion, moderate DNA degradation $(<80 \%)$ and stability of $5 \mathrm{~m}$ cytosine. Conversion efficiencies were determined to be more than $1: 10^{4}$, as judged by PCR. 


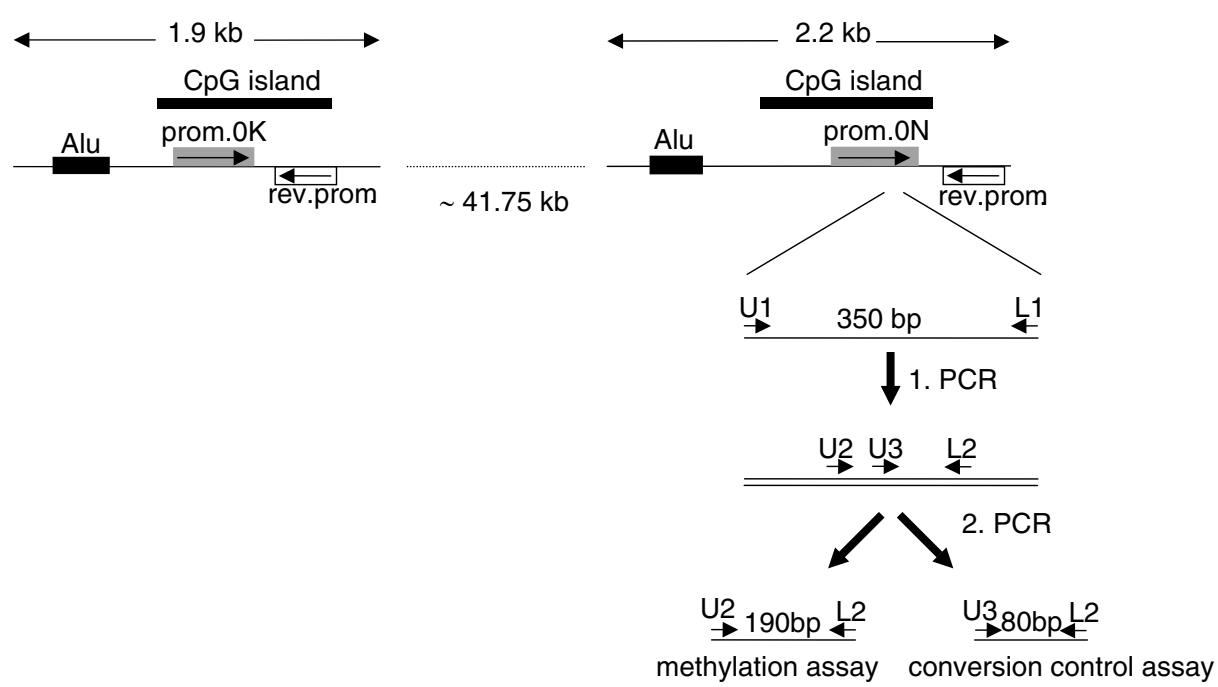

Figure 1 Structure of the $5^{\prime}$-region of the ER- $\beta$ gene and location of the methylation assay. The $5^{\prime}$ region of the human ER- $\beta$ gene (ESR2) contained in BAC clone R-712C19 (accession no. AL161756) is represented by a horizontal line. The relative positions of promoter $0 \mathrm{~K}$ and $0 \mathrm{~N}$, separated by $41.75 \mathrm{~kb}$ intervening sequence, are depicted as gray boxes, and the associated Alu repeats and reverse promoters as black and white boxes respectively. Two CpG islands associated with the promoters are represented as filled black boxes above. The location of the MSP assay for promoter ON involving two rounds of PCR is schematically shown on the right. Nucleotide positions of the primer are given in the Methods section. For detection of methylation, primer U2 is used in combination with primer L2. Primers U3 and L2 are used to monitor the bisulfite conversion reaction.

\section{Characteristics of the methylation assay}

Next to completeness of the bisulfite conversion, a second critical aspect of methylation analyses is the compromise between sensitivity and specificity. A high specificity can easily be obtained when several methylated sites are incorporated in the assay, a strategy mostly using upstream and downstream primers encompassing multiple methylated cytosine residues. However, since differences often exist between cells and tumors in methylation patterns, and as not all possible methylated sites are actually methylated in an individual cell, this strategy results in a loss of sensitivity. Therefore, to reach maximal sensitivity, we incorporated only one methylated $\mathrm{CpG}$ site in the assay and exhaustively optimized reaction conditions, using model templates to reach a $\Delta \mathrm{ct}$ of more than 17 cycles between methylated and nonmethylated templates (Fig. 2). This specificity is more than sufficient for detection of one methylated template among $10^{5}$ unmethylated template molecules. To determine the sensitivity of the assay in the genomic context, decreasing amounts of methylated cells (MDA-MB-435) were diluted in a background of $4 \times 10^{4}$ unmethylated cells (MCF-7). The number of tests positive for methylation of total tests performed is reported in Table 1.
Approximately 100 methylated tumor cells can be reliably detected by the assay. To correlate the mRNA expression of ER- $\beta$ and the methylation status as determined by our assay, real-time PCR data from cDNA were compared with the results of the methylation assay on DNA from the same tumor samples (Table 2). In comparing ER- $\beta$ and GPDH signals, a $\Delta$ ct of 5.42-7.25 was observed for three of ten tumor samples. This range was also observed for benign breast tissue (data not shown), and it corresponds to an amount of ER- $\beta$ mRNA about 30-150-fold lower than those of the higher expressed housekeeping gene GPDH. All these three tumors with persisting ER- $\beta$ expression displayed a negative result of the methylation assay. In contrast, for six tumor samples, no amplification of ER- $\beta$ was achievable. The resulting $\Delta$ ct of over 15 corresponds to an amount of the ER- $\beta$ mRNA at least $3 \times 10^{4}$-fold lower than those of GPDH mRNA. All those tumors showed a positive result for methylation. In one sample, a residual expression of ER- $\beta$ was detectable with $\Delta$ ct of 14.15 (more than $1.8 \times 10^{4}$-fold lower ER- $\beta$ than GPDH) despite a positive result of the methylation assay. Presumably, this low ER- $\beta$ expression resulted from residual benign epithelial cells in this tissue sample. Thus, seven of the ten breast tumors displayed a total or nearly total loss of ER- $\beta$ mRNA expression, correlating with a positive 


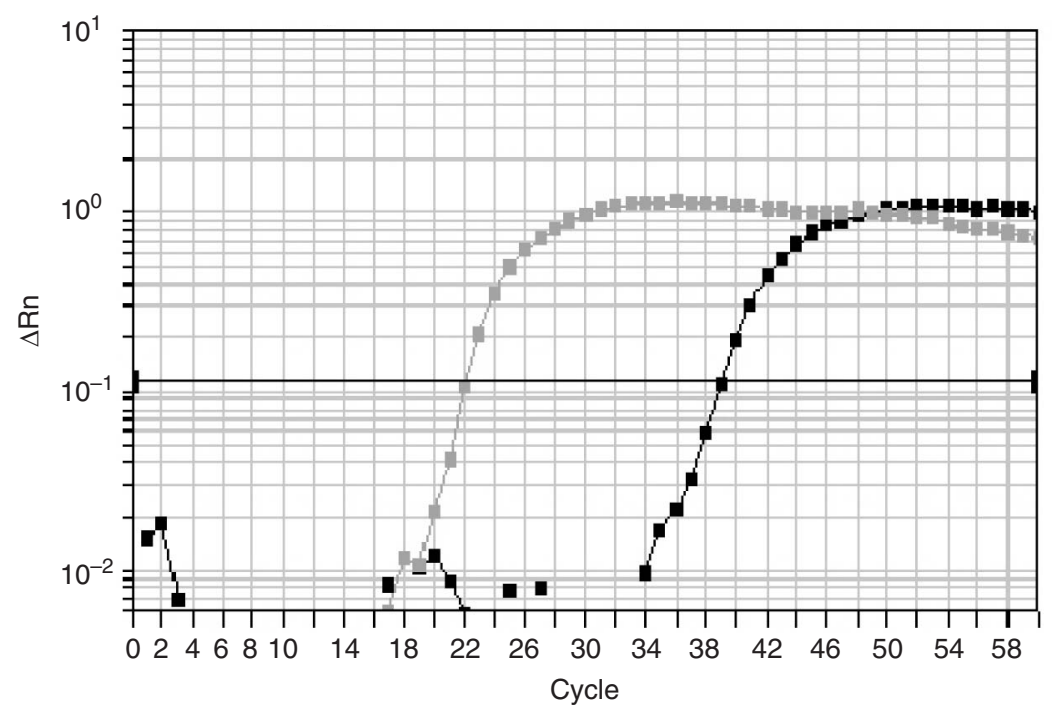

Figure 2 Specificity of the methylation assay using optimized reaction conditions on model templates. Model templates were generated by PCR incorporating the nucleotide changes resulting from either a methylated $(\mathrm{C})$ or nonmethylated $(\mathrm{T})$ cytosine at nucleotide position 82,306 according to BAC clone R-712C19 (accession no. AL161756). Subsequently, in order to determine cross-reactivity, equal amounts of both model templates were tested in PCR, using primer U2 and L2 for the detection of the 'methylated' model template (gray curve) in comparison with the 'nonmethylated' model template (black curve). As shown, optimization of PCR conditions resulted in a $\Delta$ ct of more than 17 cycles. The same results were obtained for reverse experiments using an upper primer specific for 'nonmethylated' molecules.

Table 1 Sensitivity of the ER- $\beta$ methylation assay. Decreasing amounts of methylated cells (MDA-MB-435) were diluted in a background of $4 \times 10^{4}$ unmethylated cells (MCF-7), and five independent MSP assays were performed. The number and percentage of tests positive for methylation are given

\section{No. of methylated cells \\ (among $4 \times 10^{4}$ unmethylated cells)}

\begin{tabular}{cl}
\hline $200-400$ & $5 / 5(100 \%)$ \\
$100-200$ & $5 / 5(100 \%)$ \\
$50-100$ & $4 / 5(80 \%)$ \\
$20-50$ & $2 / 5(40 \%)$ \\
\hline
\end{tabular}

result of the methylation assay $(P=0.008)$. These results are in good agreement with several reports showing loss of ER- $\beta$ expression in the majority of breast cancers (Speirs et al. 1999, Iwao et al. 2000, Shaw et al. 2002, Park et al. 2003, Skliris et al. 2003). For example, only 7 out of 33 breast cancer samples analyzed by Zhao et al. (2003) by real-time PCR displayed levels of ER- $\beta$ mRNA comparable to benign breast tissue. In summary, these results demonstrate that this methylation-specific PCR is a valid assay for evaluation of the epigenetic regulation of ER- $\beta$ and can be used as a surrogate marker for ER- $\beta$ expression status.

\section{Analysis of ER- $\beta$ methylation in breast cancer and premalignant lesions}

The methylation status of ER- $\beta$ from breast tissue samples $(n=175)$ was evaluated by the assay
Table 2 Comparison of ER- $\beta$ mRNA expression and promoter methylation status. Ten breast tumors were analyzed for ER- $\beta$ mRNA expression by real-time PCR and the relative expression values ( $\Delta$ ct using GPDH as endogenous control), and S.D. of three measurements are given. When no amplification of ER- $\beta$ was achievable, a threshold value $(>15)$ was used. The results of the methylation analysis obtained by MSP assay are given as '-' and '+' respectively

\begin{tabular}{lcc}
\hline Tumor & $\begin{array}{c}\text { ER- } \beta \text { mRNA expression } \\
\Delta \text { Ct }_{\text {ER- } \beta}-\text { - }_{\text {GPDH }} \text { (s.D.) }\end{array}$ & $\begin{array}{c}\text { ER- } \beta \text { promoter } \\
\text { methylation assay }\end{array}$ \\
\hline 1 & $5.42(0.73)$ & - \\
2 & $7.25(0.47)$ & - \\
3 & $6.38(0.54)$ & - \\
4 & $14.15(0.69)$ & + \\
5 & $>15$ & + \\
6 & $>15$ & + \\
7 & $>15$ & + \\
8 & $>15$ & + \\
9 & $>15$ & + \\
10 & $>15$ & + \\
\hline
\end{tabular}

described above. Samples were classified by histology as 25 benign breast tissues, 21 benign breast tissues from patients with a mammary carcinoma, three papillomas, 28 fibroadenomas, 17 ductal hyperplasias, seven DCIS and 74 breast cancers. As shown in Table 3, an absence of methylation was seen in normal breast tissue, regardless of the existence of breast cancer in the environment. Furthermore, all papillomas showed no methylation. In contrast, in fibroadenoma and ductal hyperplasia, weak methylation could be detected $(P<0.001)$. In addition, $6 / 7$ DCIS showed 
Table 3 Frequency of ER- $\beta$ methylation. Methylation status of 175 breast tissue samples was analyzed by MSP assay. For invasive carcinomas positive for methylation, 'strong' signals were detected by real-time PCRs with fluctuations in the $\Delta$ ct of $<2$ among samples. Real-time PCR signals with $\Delta$ ct values of $6-8$, as compared with invasive carcinomas, were characterized as 'weak'. 'None' indicates signals below primer cross-reactivity $(\Delta \mathrm{ct}>17)$

\begin{tabular}{|c|c|c|c|c|}
\hline \multirow[b]{2}{*}{ Tissue } & \multirow[b]{2}{*}{$n$} & \multicolumn{3}{|c|}{$\begin{array}{l}\text { Signal strength } \\
\text { of MSP assay }\end{array}$} \\
\hline & & Strong & Weak & None \\
\hline Normal breast & 25 & & & 25 \\
\hline $\begin{array}{l}\text { Normal breast from } \\
\text { tumor patients }\end{array}$ & 21 & & & 21 \\
\hline Papilloma & 3 & & & 3 \\
\hline Fibroadenoma & 28 & & 26 & 2 \\
\hline Ductal hyperplasia & 17 & & 16 & 1 \\
\hline DCIS & 7 & & 6 & 1 \\
\hline Invasive carcinoma & 74 & 52 & & 22 \\
\hline
\end{tabular}

weak methylation $(P<0.001)$. Strong methylation was seen in $70.3 \%(52 / 74)$ of the invasive carcinomas. The remaining $29.7 \%$ showed no methylation. The observed differences in the signal strength of the MSP assay depend on the number of methylated cells in the sample. In contrast to mRNA and protein expression, which are metric values, the methylation state of a defined position on the DNA, as analyzed in the assay used here, is a priori a nominal value, which is either present or absent. However, if only a very small portion of the cells in the sample show methylation, a weak signal results, since no saturation of the primary amplification product from these cells will occur in the first-round PCR. It can be broadly estimated that in the benign/premalignant conditions exhibiting a weak methylation signal, about $0.1-1 \%$ of the total cells are methylated, in contrast to a range of $20-100 \%$ in the case of a strong signal in the methylation assay, as observed for invasive cancer cases.

\section{ER- $\beta$ methylation in breast cancer patients with unfavorable prognosis}

To evaluate a potential prognostic value of ER- $\beta$ promoter methylation, we tested a panel of breast tumors which had been previously characterized by gene-expression profiling (Ahr et al. 2001), and for which follow-up data were available (Ahr et al. 2002). As shown in Fig. 3, methylation was observed predominantly in the tumors which grouped in the branch marked by a gray bar $(P<0.001)$. This subgroup contains most $(9 / 12)$ of the patients with relapse during follow-up $(P=0.016)$. In using ER- $\beta$ promoter methylation alone as a prognostic factor, there is an inverse trend of the methylation status and prognosis, which is, however, not yet significant $(P=0.26)$. While only $10.5 \%(2 / 19)$ of the tumors negative for methylation showed a relapse, this portion increased to $27.8 \%(10 / 36)$ among the tumors positive for methylation. These results agree with data from several recent studies showing a positive correlation of ER- $\beta$ expression and prognosis (Omoto et al. 2001, Esslimani-Sahla et al. 2004, Myers et al. 2004, Palmieri et al. 2004).

\section{Possible mechanisms for ER- $\beta$ promoter methylation}

Several mechanisms are conceivable that could result in promoter methylation of ER- $\beta$ in the cell. The observation of associated promoters just $1 \mathrm{~kb}$ downstream of both promoter $0 \mathrm{~N}$ and $0 \mathrm{~K}$, but with a

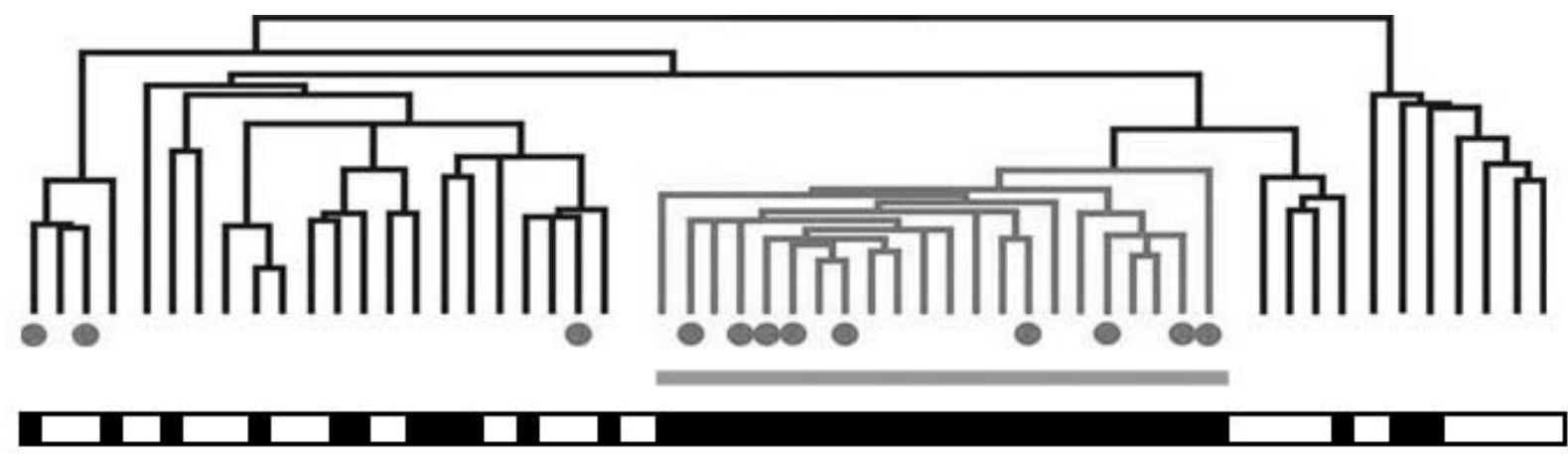

Figure 3 Correlation of gene-expression profiling and ER- $\beta$ methylation. Fifty-five tumors from patients with known follow-up were analyzed by gene-expression profiling and grouped by unsupervised clustering, as described previously (Ahr et al. 2002). Patients with relapse are marked by dots, and the high-risk group by a gray bar. The ER- $\beta$ methylation status of the tumor is indicated below. Black boxes mark samples positive for methylation. 


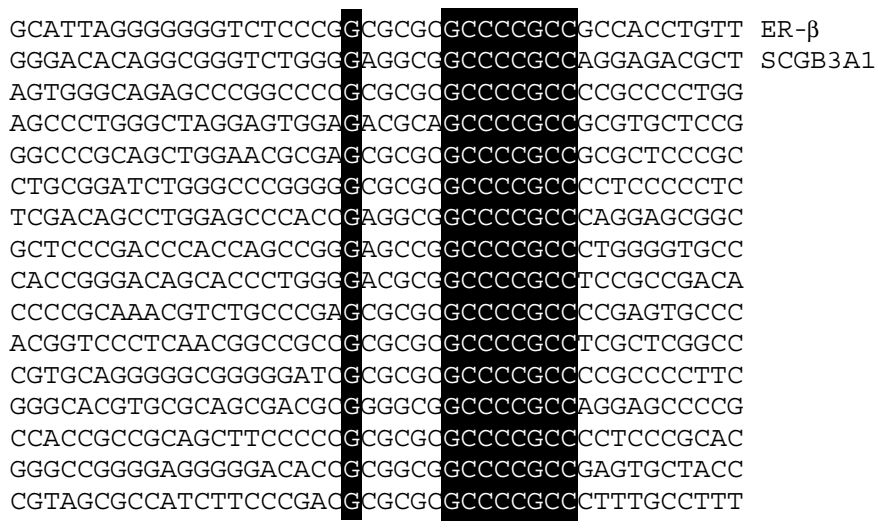

Figure 4 Sequence comparison of BLAST results from the homologous regions in the promoters of ER- $\beta$ and SCGB3A1. Sequences from the promoter of ER- $\beta$ and SCGB3A1 surrounding their region of homology were used as a query in a BLAST search of the human genome. Fourteen database hits from the output of the search are shown together with ER- $\beta$ and SCGB3A1 in a multiple alignment. Nucleotide residues that are perfectly conserved are shown inverted.

reverse orientation (Fig. 1), might lead to an attractive model, where antisense transcripts are transcribed from these promoters. The generation of the antisense transcript could result in double-stranded RNA, leading to methylation of the upper-strand promoter, a mechanism which has been described for epigenetic silencing and imprinting (Ogawa \& Lee 2002, Tufarelli et al. 2003, Tagoh et al. 2004). To detect such possible antisense transcripts originating from the reverse promoter downstream of promoter $0 \mathrm{~N}$, we performed RT-PCR analyses, using cDNA specifically primed with different sense primers in the region encompassing and surrounding promoter $0 \mathrm{~N}$. Total RNA from several tumors, as well as cell lines with either methylated (MDA-MB-435) or unmethylated (MCF7) status of promoter $0 \mathrm{~N}$, was used for cDNA generation. RNA was depleted of residual genomic DNA by two rounds of DNase treatment, and the extent of DNA digestion was subsequently assessed by genomic PCR (see Methods). However, despite numerous efforts, we were unable to detect any antisense transcripts in this region. This was in line with BLAST and FASTA searches of EST databases that resulted in no hits. We next tested whether induction of de novo methylation in cell lines could be achieved by transfection with shRNA. Transcriptional silencing by targeting siRNAs against $\mathrm{CpG}$ sites was recently described by Kawasaki and Taira (2004) and Morris et al. (2004). We introduced PCR products containing shRNA targeted against various $\mathrm{CpG}$ sites in promoter $0 \mathrm{~N}$ under the control of the human U6 promoter in various cell lines, and analyzed the DNA at days 2, 5 and 10 after transfection for methylation of the ER- $\beta$ promoter. Neither a change in expression of the ER- $\beta$ gene nor methylation of promoter $0 \mathrm{~N}$ was detectable (data not shown).

\section{Identification of a sequence motif putatively associated with promoter methylation}

Although numerous genes have been shown to be methylated in breast cancer, only a limited number were reported to be epigenetically modified in premalignant lesions. Since SCGB3A1, also termed 'HIN-1' (Krop et al. 2001), has been shown to be methylated in a manner resembling ER- $\beta$, we compared the promoters of both genes for regions of homology. No extended similarities were identified except a short motif encompassing the "APRTmouse_US'-site (TFD\# S00216). The 'APRT-mouse US'-site, which contains an SP1 consensus sequence, was originally identified in the promoter of the APRT gene (Park \& Taylor 1988 and has already been reported to be involved in methylation processes (Siegfried et al. 1999). BLAST searches with both promoter sequences of ER- $\beta$ and SCGB3A1 respectively identified a number of other human genes containing similar sequences. In a multiple sequence alignment of the BLAST output (Fig. 4), this motif could be extended to a possible consensus sequence G-(N)5-GCCCCGCC. Since the BLAST algorithm is not suitable for pattern searches with short sequence motifs, we then performed a global pattern search of the assembled human genome sequence (GenBank Release 35.1: 3,149,005,344 nucleotides), using the above consensus sequence with the FindPatterns program. The search returned 17605 hits representing 977 different motifs, most of which were at frequencies 
expected by chance (about 24 times). The exact sequence of the ER- $\beta$ motif was detected 45 times. To determine whether this sequence motif might be of functional relevance, we analyzed the surrounding $2 \mathrm{~kb}$ sequence of all 45 loci of the exact ER- $\beta$ motif in the human genome. The results of these analyses are compiled in Table 4. Interestingly, all sequences were predicted to have promoter activity; moreover, 44 of these 45 promoters were associated with a CGI. Furthermore, all sequences were located immediately upstream of the start of described mRNAs. No strand specificity of the motif relative to the associated gene was observed. For 42 of the 45 sequences, the corresponding genes were identified (Table 4). We analyzed the expression of the 42 genes in breast cancer samples, using publicly available datasets from microarray analyses. We chose studies by Sorlie et al. (2001) and Perou et al. (2000) that allow comparison of gene expression in breast cancer and benign breast tissue. Data for 18 genes were available from those studies, and most of them consistently showed decreased expression in breast cancer samples (Table 4). For four genes (E2F1, TOB, SOS1 and BST1) that did not show reduced expression in breast cancer, a possible confounding effect of tumor-infiltrating lymphocytes was analyzed by using microarray data from van't Veer et al. (2002). Significant values for three of the genes (E2F1, TOB and SOS1) were observed. This suggests that the possible loss of their expression in breast cancer compared with benign breast tissue is overwhelmed by the expression in tumor-associated lymphocytes. STK11, whose expression was not analyzed in the Sorlie et al. and Perou et al. data sets, is also known as LKB1 (Marignani 2005), a wellknown tumor suppressor kinase that is lost in PeutzJeghers syndrome (PJS). Patients with PJS develop cancer of epithelial tissue origin. Methylation of STK11 has already been described for cases of papillary breast carcinomas (Esteller et al. 2000) and colorectal carcinomas (Trojan et al. 2000). Of the genes for which microarray data were available, the most significant difference in expression was found for NFIB $(P<0.0001)$, a transcription factor critical for lung and brain development (Steele-Perkins et al. 2005). Krop et al. (2003) reported that SCGB3A1 was found to be methylated only in sporadic cases of breast cancer in contrast to the hereditary forms resulting from BRCA1 mutation. Interestingly, in comparing the expression of NFIB in BRCA1 mutated $(n=18)$ and sporadic $(n=97)$ cases with microarray data from van't Veer et al. (2002), a significant difference $(P=0.0007)$ was observed with loss of NFIB expression in sporadic cases.

\section{Discussion}

The highly sensitive MSP assay presented here demonstrated a strong inverse correlation of ER- $\beta$ mRNA expression with the methylation status of the promoter. The analysis of methylation, moreover, offers important advantages over assaying for ER- $\beta$ expression itself. While the analysis of ER- $\beta$ methylation is a 'positive assay', the determination of the loss of expression itself would be a 'negative assay'. Detecting the loss of expression in only a small number of cells by such a negative assay is highly problematic if not impossible, since a high background signal is generated by the large number of cells still expressing the gene. This loss in sensitivity can be circumvented if the highly sensitive methylation assay is used as a surrogate marker to monitor the loss of ER- $\beta$ expression. Methylation of $\mathrm{CpG}$ sites in promoter $0 \mathrm{~N}$ of the ER- $\beta$ gene seems to be a common event in breast cancer. More than two-thirds of all carcinomas showed methylation and an associated decrease in the expression of ER- $\beta$ mRNA. Furthermore, methylation was already detectable in ductal hyperplasia and premalignant lesions such as DCIS. This result suggests that ER- $\beta$ and regulation of its expression might play a pivotal role in the development of malignant breast tumors, and underlines its putative function as a tumor-suppressor gene. We hypothesize that methylation of the ER- $\beta$ promoter region and the resultant suppression of mRNA expression is an early event in the development of endocrine-dependent cancer. These results agree with Roger et al. (2001), who showed the early loss of expression of ER- $\beta$ receptor protein in premalignant breast lesions. Similar data were also obtained for prostate tissue. Zhu et al. (2004) established that ER- $\beta$ gene silencing by promoter methylation results in a decrease of expression, not only in cancer tissue but also in premalignant stages. Of special interest is that we detected no methylation in benign breast tissue from breast cancer patients, suggesting that methylation of the ER- $\beta$ promoter is a focal event, and not a generally occurring phenomenon in the breast (as resulting from aging processes). The function of ER- $\beta$ in mammary tissue is not completely understood. However, while early observations were often conflicting, more recent data suggest an important role as a tumor-suppressor gene. On the basis of these results, agonistic drugs which selectively bind ER- $\beta$ could have potential as protective compounds. This view might be supported by data from hormone replacement therapy (HRT), since ER- $\beta$ receptor is known to be constitutively expressed in colorectal tissue, and its stimulation could be 


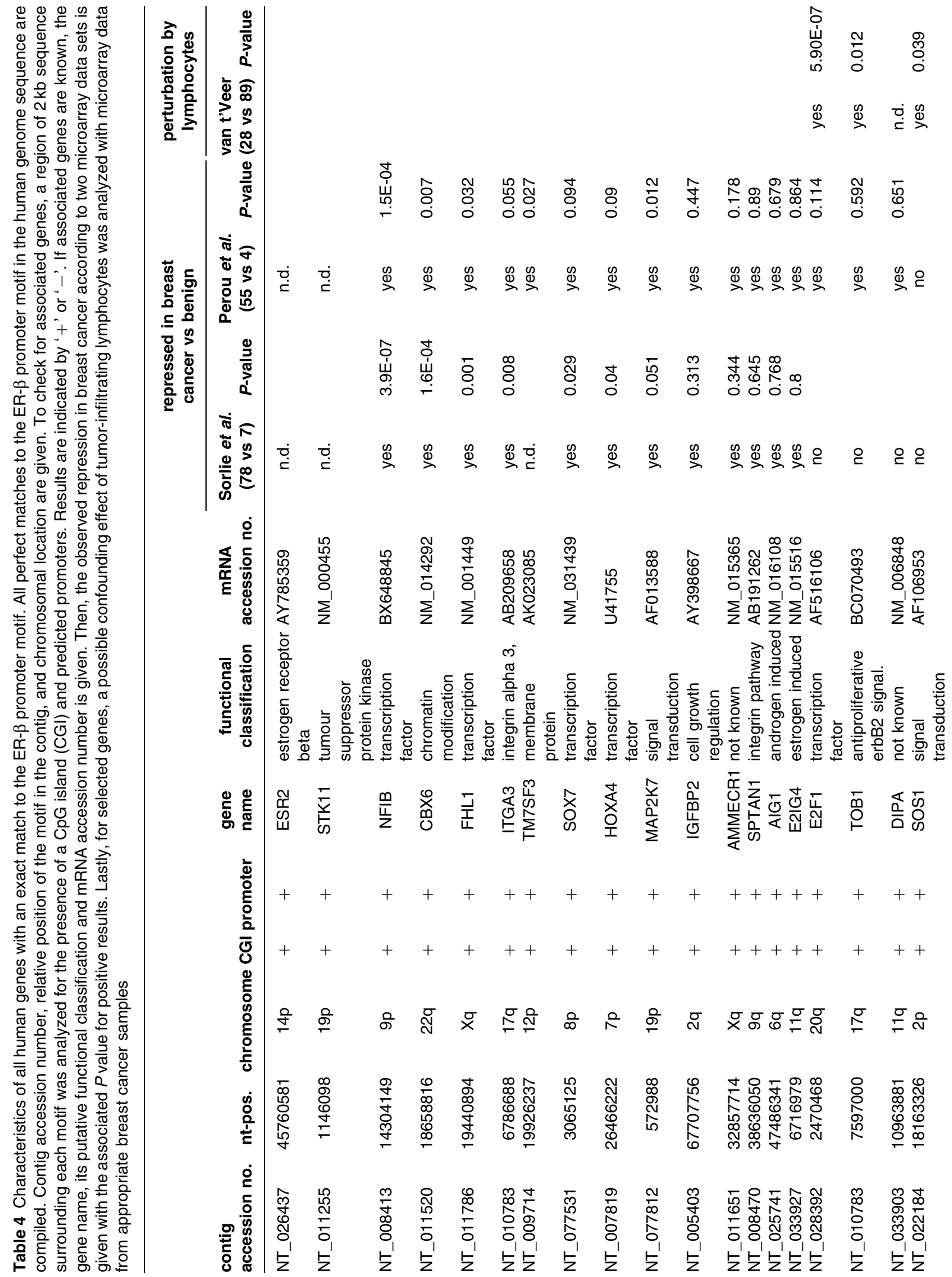




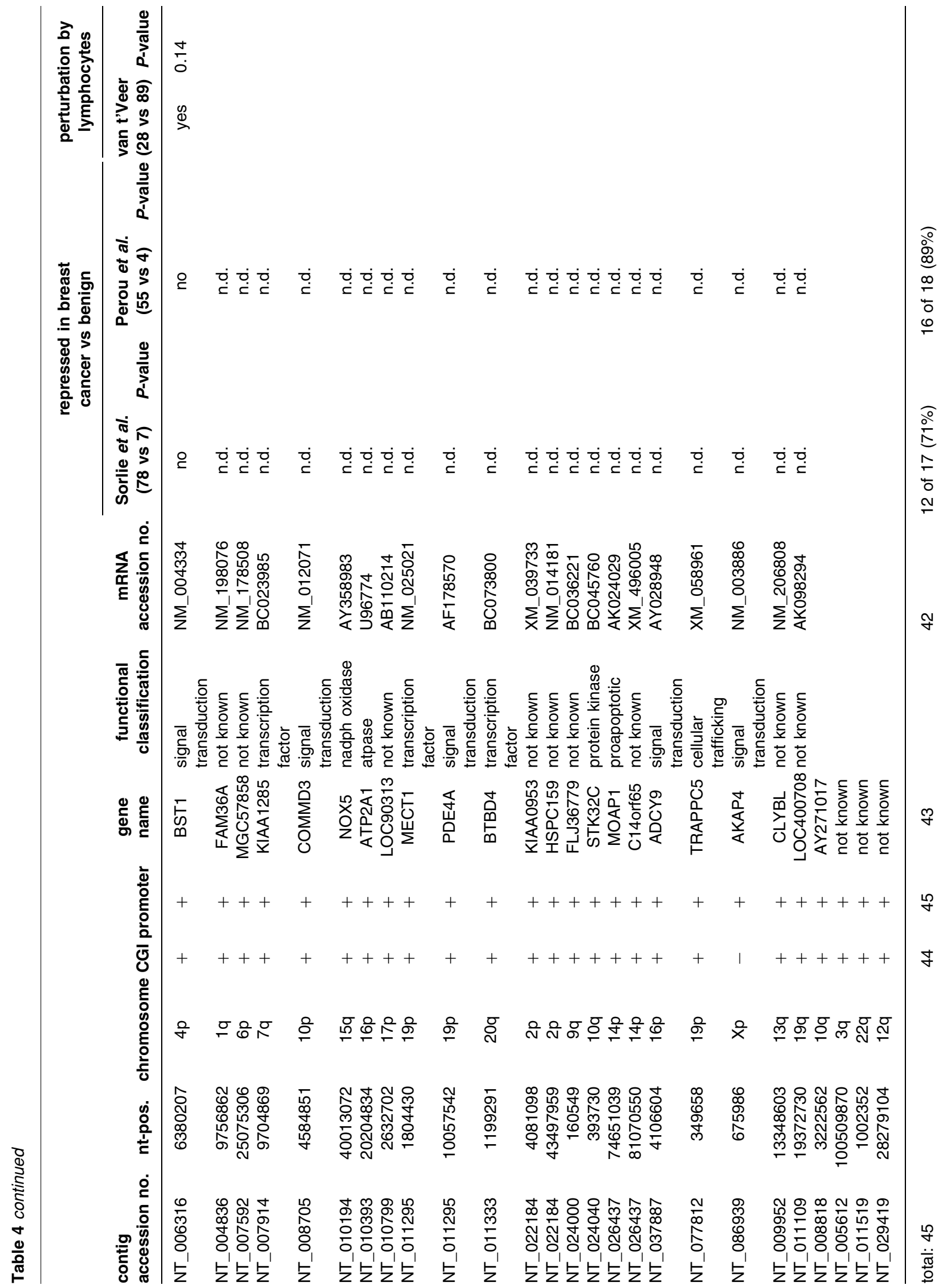


responsible for the protective effect of HRT against the development of colorectal cancer (Chlebowski et al. 2004). Our data suggest that methylation of ER- $\beta$ promoter is an early event in malignant transformation of breast tissue. As a risk marker for the malignant potential of breast epithelial cells, it could be useful in classifying benign and premalignant breast lesions. Moreover, even if we could not yet detect a significant correlation, the methylation status of ER- $\beta$ might have prognostic potential. By analyzing breast cancer patients classified previously by gene-expression profiling, we detected ER- $\beta$ methylation predominantly in a subgroup of patients characterized by unfavorable prognosis. It still remains unclear how DNA methyltransferases establish specific methylation patterns within a cell. Epigenetic regulation of the genome might involve several different pathways that contribute to methylation. One mechanism described for a number of genes is the generation of antisense transcripts from a reverse promoter (Ogawa \& Lee 2002, Tufarelli et al. 2003, Tagoh et al. 2004). This possibility is especially intriguing since we detected reverse promoters in close proximity with both promoter $0 \mathrm{~K}$ and $0 \mathrm{~N}$ of ER- $\beta$. Although we were unable to detect antisense transcripts from the reverse promoter, it is possible that those transcripts exist in vivo only for a short window of time immediately preceding the methylation process. A second hypothesis of the induction of DNA methylation is the involvement of RNAi-dependent mechanisms resulting from endogenous noncoding RNA (ncRNA). The experimental induction of methylation by such an approach has been described recently (Kawasaki \& Taira 2004, Morris et al. 2004). Several causes could account for our failure to induce methylation of the ER- $\beta$ promoter by this strategy. First, both Morris et al. (2004) and Kawasaki \& Taira (2004) transfected synthetic siRNA, in contrast to the shRNA used in our experiments, which has to be transcribed and processed to siRNAs in the cell. Secondly, in contrast to Kawasaki and Taira, Morris et al. observed a stringent dependency of the observed effect on nuclear transport of the siRNA by a shuttle protein (MPG). Finally, the obtained results may also differ depending on the cell type used. A third model for promoter methylation involves the targeting of DNMTs to the promoter by association with transcription factors, as described for Myc in recent work by Brenner et al. (2005) and Di Croce et al. (2002). Hints for such a mechanism could come from shared binding sites for distinct transcription factors in the promoter of genes that share a common methylation profile. Accordingly, we used homology comparisons of the promoters of ER- $\beta$ and
SCGB3A1 and succeeded in identifying such a shared motif. Interestingly, a global search of the human genome found that all 45 occurrences of the motif with the exact sequence from ER- $\beta$ are in the promoter region of human genes. Further data on these genes from microarray analyses suggest that most of them even show decreased expression in breast cancer tissue and might be prone to methylation in this disease. Intriguingly, the majority (6/9) of those genes with most significant downregulation $(P<0.05)$ in mammary carcinomas are themselves directly implicated in transcriptional regulation (ESR2, NFIB, CBX6, FHL1, SOX7 and HOXA4), while the remaining three are involved in signal transduction (STK11, ITGA3 and TM7SF3), and we might speculate that loss of these factors may trigger further changes in expression patterns in the tumor cell.

\section{Funding}

This work was supported by grants from the Margarete Bonifer-Stiftung, Bad Soden; the BANSSStiftung, Biedenkopf; and the Dr Robert PflegerStiftung, Bamberg. There is no conflict of interest to declare.

\section{References}

Ahr A, Holtrich U, Solbach C, Scharl A, Strebhardt K, Karn T \& Kaufmann M 2001 Molecular classification of breast cancer patients by gene expression profiling. Journal of Pathology 195 312-320.

Ahr A, Karn T, Solbach C, Seiter T, Strebhardt K, Holtrich U \& Kaufmann M 2002 Identification of high risk breast-cancer patients by gene expression profiling. Lancet 359 131-132.

Bardin A, Boulle N, Lazennec G, Vignon F \& Pujol P 2004 Loss of ERbeta expression as a common step in estrogen-dependent tumor progression. Endocrine-Related Cancer 11 537-551.

Bird A 2002 DNA methylation patterns and epigenetic memory. Genes and Development 16 6-21.

Brenner C, Deplus R, Didelot C, Loriot A, Vire E, De Smet C, Gutierrez A, Danovi D, Bernard D, Boon T, Pelicci PG, Amati B, Kouzarides T, de Launoit Y, Di Croce L \& Fuks F 2005 Myc represses transcription through recruitment of DNA methyltransferase corepressor. EMBO Journal 24 336-346.

Castanotto D, Li H \& Rossi JJ 2002 Functional siRNA expression from transfected PCR products. $R N A \mathbf{8}$ 1454-1460.

Chlebowski RT, Wactawski-Wende J, Ritenbaugh C, Hubbell FA, Ascensao J, Rodabough RJ, Rosenberg CA, Taylor VM, Harris R, Chen C, Adams-Campbell LL \& White E; Women's Health Initiative Investigators 2004 
Estrogen plus progestin and colorectal cancer in postmenopausal women. New England Journal of Medicine 350 991-1004.

Di Croce L, Raker VA, Corsaro M, Fazi F, Fanelli M, Faretta M, Fuks F, Lo Coco F, Kouzarides T, Nervi C, Minucci S \& Pelicci PG 2002 Methyltransferase recruitment and DNA hypermethylation of target promoters by an oncogenic transcription factor. Science 295 1079-1082.

Esslimani-Sahla M, Simony-Lafontaine J, Kramar A, Lavaill R, Mollevi C, Warner M, Gustafsson JA \& Rochefort H 2004 Estrogen receptor beta (ER beta) level but not its ER beta cx variant helps to predict tamoxifen resistance in breast cancer. Clinical Cancer Research 10 5769-5776.

Esteller M, Avizienyte E, Corn PG, Lothe RA, Baylin SB, Aaltonen LA \& Herman JG 2000 Epigenetic inactivation of LKB1 in primary tumors associated with the Peutz-Jeghers syndrome. Oncogene 19 164-168.

Fitzpatrick GV, Soloway PD \& Higgins MJ 2002 Regional loss of imprinting and growth deficiency in mice with a targeted deletion of KvDMR1. Nature Genetics 32 426-431.

Frommer M, McDonald LE, Millar DS, Collis CM, Watt F, Grigg GW, Molloy PL \& Paul CL 1992 A genomic sequencing protocol that yields a positive display of 5-methylcytosine residues in individual DNA strands. PNAS 89 1827-1831.

Heilig R, Petit JL, Vico V, Dasilva C, Robert C, Wincker P, Brottier P, Cattolico L, Barbe V, Pelletier E et al. 2001 Sequencing of the human chromosome 14, Genbank Accession AL161756, Version AL161756.6.

Herman JG, Graff JR, Myohanen S, Nelkin BD \& Baylin SB 1996 Methylation-specific PCR: a novel PCR assay for methylation status of $\mathrm{CpG}$ islands. PNAS $\mathbf{9 3}$ 9821-9826.

Hock B, Bohme B, Karn T, Yamamoto T, Kaibuchi K, Holtrich U, Holland S, Pawson T, RubsamenWaigmann H \& Strebhardt K 1998 PDZ-domainmediated interaction of the Eph-related receptor tyrosine kinase EphB3 and the ras-binding protein AF6 depends on the kinase activity of the receptor. PNAS 95 9779-9784.

Holtrich U, Brauninger A, Strebhardt K \& RubsamenWaigmann H 1991 Two additional protein-tyrosine kinases expressed in human lung: fourth member of the fibroblast growth factor receptor family and an intracellular protein-tyrosine kinase. PNAS $\mathbf{8 8}$ 10411-10415.

Holtrich U, Wolf G, Brauninger A, Karn T, Bohme B, Rubsamen-Waigmann H \& Strebhardt K 1994 Induction and down-regulation of PLK, a human serine/threonine kinase expressed in proliferating cells and tumors. PNAS 91 1736-1740.

Iwao K, Miyoshi Y, Egawa C, Ikeda N \& Noguchi S 2000 Quantitative analysis of estrogen receptor-beta mRNA and its variants in human breast cancers. International Journal of Cancer 88 733-736.

Kawasaki H \& Taira K 2004 Induction of DNA methylation and gene silencing by short interfering RNAs in human cells. Nature 431 211-217.

Krop IE, Sgroi D, Porter DA, Lunetta KL, LeVangie R, Seth P, Kaelin CM, Rhei E, Bosenberg M, Schnitt S et al. 2001 HIN-1, a putative cytokine highly expressed in normal but not cancerous mammary epithelial cells. PNAS 98 9796-9801.

Krop I, Maguire P, Lahti-Domenici J, Lodeiro G, Richardson A, Johannsdottir HK, Nevanlinna H, Borg A, Gelman R \& Barkardottir RB et al. 2003 Lack of HIN-1 methylation in BRCA1-linked and "BRCA1-like" breast tumors. Cancer Research 63 2024-2027.

Li LC, Yeh CC, Nojima D \& Dahiya R 2000 Cloning and characterization of human estrogen receptor beta promoter. Biochemical and Biophysical Research Communications 275 682-689.

Mann MR \& Bartolomei MS 1999 Towards a molecular understanding of Prader-Willi and Angelman syndromes. Human Molecular Genetics 8 1867-1873.

Marignani PA 2005 LKB1, the multitasking tumour suppressor kinase. Journal of Clinical Pathology 58 15-19.

Matthews J \& Gustafsson JA 2003 Estrogen signaling: a subtle balance between ER alpha and ER beta. Molecular Interventions 3 281-292.

Morris KV, Chan SW, Jacobsen SE \& Looney DJ 2004 Small interfering RNA-induced transcriptional gene silencing in human cells. Science 305 1289-1292.

Myers E, Fleming FJ, Crotty TB, Kelly G, McDermott EW, O'Higgins NJ, Hill AD \& Young LS 2004 Inverse relationship between ER-beta and SRC-1 predicts outcome in endocrine-resistant breast cancer. British Journal of Cancer 91 1687-1693.

Ogawa Y \& Lee JT 2002 Antisense regulation in X inactivation and autosomal imprinting. Cytogenetic and Genome Research 99 59-65.

Olek A, Oswald J \& Walter J 1996 A modified and improved method for bisulphite based cytosine methylation analysis. Nucleic Acids Research 24 5064-5066.

Omoto Y, Inoue S, Ogawa S, Toyama T, Yamashita H, Muramatsu M, Kobayashi S \& Iwase H 2001 Clinical value of the wild-type estrogen receptor beta expression in breast cancer. Cancer Letters 163 207-212.

O'Neill MJ 2005 The influence of non-coding RNAs on allele-specific gene expression in mammals. Human Molecular Genetics 14 Spec No 1 R113-120.

Palmieri C, Lam EW, Mansi J, MacDonald C, Shousha S, Madden P, Omoto Y, Sunters A, Warner M, Gustafsson JA \& Coombes RC 2004 The expression of ER beta cx in human breast cancer and the relationship to endocrine therapy and survival. Clinical Cancer Research 10 2421-2428.

Park JH \& Taylor MW 1988 Analysis of signals controlling expression of the Chinese hamster ovary aprt gene. Molecular and Cellular Biology 8 2536-2544. 
Park BW, Kim KS, Heo MK, Ko SS, Hong SW, Yang WI, Kim JH, Kim GE \& Lee KS 2003 Expression of estrogen receptor-beta in normal mammary and tumor tissues: is it protective in breast carcinogenesis? Breast Cancer Research and Treatment 80 79-85.

Paruthiyil S, Parmar H, Kerekatte V, Cunha GR, Firestone GL \& Leitman DC 2004 Estrogen receptor beta inhibits human breast cancer cell proliferation and tumor formation by causing a G2 cell cycle arrest. Cancer Research 64 423-428.

Perou CM, Sorlie T, Eisen MB, van de Rijn M, Jeffrey SS, Rees CA, Pollack JR, Ross DT, Johnsen H, Akslen LA et al. 2000 Molecular portraits of human breast tumours. Nature 406 747-752.

Prestridge DS 1995 Predicting Pol II promoter sequences using transcription factor binding sites. Journal of Molecular Biology 249 923-932.

Rein T, Zorbas H \& DePamphilis ML 1997 Active mammalian replication origins are associated with a high-density cluster of $\mathrm{mCpG}$ dinucleotides. Molecular and Cellular Biology 17 416-426.

Rein T, DePamphilis ML \& Zorbas H 1998 Identifying 5-methylcytosine and related modifications in DNA genomes. Nucleic Acids Research 26 2255-2264.

Rhodes DR, Yu J, Shanker K, Deshpande N, Varambally R, Ghosh D, Barrette T, Pandey A \& Chinnaiyan AM 2004 Large-scale meta-analysis of cancer microarray data identifies common transcriptional profiles of neoplastic transformation and progression. PNAS 101 9309-9314.

Roger P, Sahla ME, Makela S, Gustafsson JA, Baldet P \& Rochefort H 2001 Decreased expression of estrogen receptor beta protein in proliferative preinvasive mammary tumors. Cancer Research 61 2537-2541.

Schwarz DS, Hutvagner G, Du T, Xu Z, Aronin N \& Zamore PD 2003 Asymmetry in the assembly of the RNAi enzyme complex. Cell 115 199-208.

Shaw JA, Udokang K, Mosquera JM, Chauhan H, Jones JL \& Walker RA 2002 Oestrogen receptors alpha and beta differ in normal human breast and breast carcinomas. Journal of Pathology 198 450-457.

Siegfried Z, Eden S, Mendelsohn M, Feng X, Tsuberi BZ \& Cedar H 1999 DNA methylation represses transcription in vivo. Nature Genetics 22 203-206.

Skliris GP, Munot K, Bell SM, Carder PJ, Lane S, Horgan K, Lansdown MR, Parkes AT, Hanby AM, Markham AF \& Speirs V 2003 Reduced expression of oestrogen receptor beta in invasive breast cancer and its re-expression using DNA methyl transferase inhibitors in a cell line model. Journal of Pathology 201 213-220.

Sorlie T, Perou CM, Tibshirani R, Aas T, Geisler S, Johnsen H, Hastie T, Eisen MB, van de Rijn M, Jeffrey SS et al. 2001 Gene expression patterns of breast carcinomas distinguish tumor subclasses with clinical implications. PNAS 98 10869-10874.

Speirs V, Parkes AT, Kerin MJ, Walton DS, Carleton PJ, Fox JN \& Atkin SL 1999 Coexpression of estrogen receptor alpha and beta: poor prognostic factors in human breast cancer? Cancer Research 59 525-528.

Steele-Perkins G, Plachez C, Butz KG, Yang G, Bachurski CJ, Kinsman SL, Litwack ED, Richards LJ \& Gronostajski RM 2005 The transcription factor gene Nfib is essential for both lung maturation and brain development. Molecular and Cellular Biology 25 685-698.

Tagoh H, Schebesta A, Lefevre P, Wilson N, Hume D, Busslinger M \& Bonifer C 2004 Epigenetic silencing of the c-fms locus during B-lymphopoiesis occurs in discrete steps and is reversible. EMBO Journal 23 4275-4285.

Takai D \& Jones PA 2002 Comprehensive analysis of CpG islands in human chromosomes 21 and 22. PNAS 99 3740-3745.

Trojan J, Brieger A, Raedle J, Esteller M \& Zeuzem S 2000 $5^{\prime}$-CpG island methylation of the LKB1/STK11 promoter and allelic loss at chromosome 19p13.3 in sporadic colorectal cancer. Gut 47 272-276.

Tufarelli C, Stanley JA, Garrick D, Sharpe JA, Ayyub H, Wood WG \& Higgs DR 2003 Transcription of antisense RNA leading to gene silencing and methylation as a novel cause of human genetic disease. Nature Genetics $\mathbf{3 4}$ 157-165.

Ui-Tei K, Naito Y, Takahashi F, Haraguchi T, OhkiHamazaki H, Juni A, Ueda R \& Saigo K 2004 Guidelines for the selection of highly effective siRNA sequences for mammalian and chick RNA interference. Nucleic Acids Research 32 936-948.

van’t Veer LJ, Dai H, van de Vijver MJ, He YD, Hart AAM, Mao M, Peterse JL, van der Kooy K, Marton MJ, Witteveen AT et al. 2002 Gene expression profiling predicts clinical outcome of breast cancer. Nature $\mathbf{4 1 5}$ 530-536.

Zhao C, W-F Lam E, Sunters A, Enmark E, Tamburo De Bella M, Coombes RC, Gustafsson JA \& DahlmanWright K 2003 Expression of estrogen receptor $b$ isoforms in normal breast epithelial cells and breast cancer:regulation by methylation. Oncogene 22 7600-7606.

Zhu X, Leav I, Leung YK, Wu M, Liu Q, Gao Y, McNeal JE \& Ho SM 2004 Dynamic regulation of estrogen receptor-beta expression by DNA methylation during prostate cancer development and metastasis. American Journal of Pathology $1642003-2012$.

Zwart R, Sleutels F, Wutz A, Schinkel AH \& Barlow DP 2001 Bidirectional action of the Igf $2 \mathrm{r}$ imprint control element on upstream and downstream imprinted genes. Genes and Development 15 2361-2366. 